\title{
Peningkatan Imunitas dengan Konsumsi Vitamin C dan Gizi Seimbang Bagi Ibu Hamil untuk Pencegahan Covid-19
}

\author{
DOI: https://doi.org/10.32509/abdimoestopo.v5i1.1750 \\ Sitti Nurbaya, Amriati Mutmainna* \\ ${ }^{1}$ STIKES Nani Hasanuddin Makassar \\ Jl. Perintis Kemerdekaan VIII No.24 Makassar \\ *Email Korespondensi: amriatimutmainna29@gmail.com
}

\begin{abstract}
Covid-19 is increasingly rampant in a number of countries including Indonesia itself, now everyone is required to start increasing stamina, including pregnant women. Those who are pregnant, of course, must ensure that their nutritional intake can be met so that their immune system remains stable, so that dangerous viruses do not attack easily. Consuming vitamin $C$ is one of the recommended ways and also an increase in food nutrition. This community service activity is carried out to improve the quality of balanced nutritional intake of pregnant women by providing assistance in providing balanced nutrition and increasing immunity by consuming vitamin $C$ during the Covid19 pandemic. Based on this, this service activity proposes a solution to overcome the problems of PKM partners, namely providing additional food for pregnant women in the form of basic necessities and Vitamin $C$ to increase the immunity of pregnant women in preventing the transmission of Covid. The results of community service that have been carried out from April to June 2021 show that there is an increase in the knowledge of pregnant women regarding COVID-19 in the Tamalanrea Village, Makassar City.
\end{abstract}

Keywords: Covid-19, Pregnant Women, Immunity, Balanced Nutrition, Vitamin C

Abstrak - Covid-19 yang semakin marak di sejumlah Negara termasuk Negara Indonesia itu sendiri, kini semua orang diharuskan mulai meningkatkan stamina, tidak terkecuali pada ibu hamil. Mereka yang sedang hamil tentu harus memastikan asupan gizi bisa terpenuhi agar daya tahan tubuh tetap stabil, sehingga virus berbahaya tidak mudah menyerang. Mengonsumsi vitamin $\mathrm{C}$ menjadi salah satu cara yang dianjurkan dan juga peningkatan gizi pangan. Kegiatan pengabdian masyarakat ini dilakukan untuk meningkatkan kualitas asupan gizi seimbang ibu hamil yaitu dengan cara memberikan bantuan pemberian gizi seimbang dan peningkatan kekebalan tubuh dengan mengonsumsi vitamin $\mathrm{C}$ selama masa Pandemi Covid19. Berdasarkan hal tersebut maka kegiatan pengabdian ini mengajukan solusi untuk mengatasi permasalahan mitra PKM yaitu memberikan tambahan bahan pangan bagi ibu hamil dalam bentuk sembako dan Vitamin $\mathrm{C}$ untuk meningkatkan imunitas ibu hamil dalam melakukan upaya pencegahan penularan Covid. Hasil pengabdian kepada masyarakat yang telah dilaksanakan pada bulan April hingga bulan Juni tahun 2021 ini bahwa adanya peningkatan pengetahuan para ibu hamil terkait COVID-19 di Kelurahan Tamalanrea Kota Makassar.

Kata Kunci: Covid-19, Ibu Hamil, Imunitas, Gizi Seimbang, Vitamin C 


\section{PENDAHULUAN}

Virus Corona atau Covid-19 yang semakin marak di sejumlah negara, kini semua orang diharuskan mulai meningkatkan stamina, tak terkecuali pada ibu hamil. Mereka yang sedang hamil tentu harus memastikan asupan gizi bisa terpenuhi agar daya tahan tubuh tetap stabil, sehingga virus berbahaya tidak mudah menyerang. Dalam upaya meningkatkan kekebalan tubuh di tengah pandemi Covid-19. (Adriani, M \& Wirjatmadi, B, 2012)

Sejak bulan Februari 2020 Indonesia dilanda Pandemi covid 19. Setelah beberapa Negara terlebih dahulu dilanda pandemic Covid 19, seperti Wuhan China, Italia, Spanyol dan Amerika. Covid 19 belum ada obat dan Immunisasinya, penularan sangat cepat melalui droplet Infaksi, dengan cara kontak langsung dengan Pasien Covid 19.Jumlah terpapar Covid 19 di Indonesia update 8 juni 2020 pukul 12.00 (gugus tugas covid 19 19, 2020) sebagai berikut ; ODP 38.791, PDP 14.010, Positif 32.003, Sembuh 10.904, Meninggal 1.883. data dari 34 Provinsi, dan 422 Kabupaten / Kota. Pandemi covid telah memporakporandakan tatanan ekonomi, social dan pelayanan kesehatan di dunia, juga di Negara Indonesia.

Mengonsumsi vitamin $\mathrm{C}$ menjadi salah satu cara yang dianjurkan dan juga peningkatan gizi pangan. Kegiatan pengabdian masyarakat ini dilakukan untuk meningkatkan kualitas asupan gizi seimbang ibu hamil yaitu dengan cara memberikan bantuan pemberian Sembako dan peningkatan kekebalan tubuh dengan konsumsi vitamin C selama masa Pandemi Covid19.

Virus Corona adalah bagian dari keluarga virus yang menyebabkan penyakit pada hewan ataupun juga pada manusia. Di Indonesia, masih melawan Virus Corona hingga saat ini, begitupun juga di negara-negara lain. Jumlah kasus Virus Corona terus bertambah dengan beberapa melaporkan kesembuhan, tapi tidak sedikit yang meninggal. Usaha penanganan dan pencegahan terus dilakukan demi melawan COVID-19 dengan gejala mirip Flu. Kasusnya dimulai dengan pneumonia atau radang paru-paru misterius pada Desember 2019. Kasus infeksi pneumonia misterius ini memang banyak ditemukan di pasar hewan tersebut. Virus Corona atau COVID-19 diduga dibawa kelelawar dan hewan lain yang dimakan manusia hingga terjadi penularan.

Konsep teori yang digunakan dalam pengabdian kepada masyarakat (PKM) ini adalah konsep kuantitatif dengan pendekatan cross sectional. Pengabdian kepada masyarakat ini untuk melihat gambaran peningkatan imunitas dengan konsumsi vitamin $\mathrm{C}$ dan gizi seimbang bagi ibu hamil untuk pencegahan Covid-19.

Virus Corona sebetulnya tidak asing dalam dunia kesehatan hewan, tapi hanya beberapa jenis yang mampu menginfeksi manusia hingga menjadi penyakit radang paru. Kasus ini diduga berkaitan dengan pasar hewan Huanan di Wuhan yang menjual berbagai jenis daging binatang,termasuk yang tidak biasa dikonsumsi seperti ular, kelelawar, dan berbagai jenis tikus. Dengan latar belakang tersebut, Virus Corona bukan kali ini saja memuat warga dunia panik. Memiliki gejala yang sama-sama mirip Flu, Virus Corona berkembang cepat hingga mengakibatkan infeks yang lebih parah dan gagal organ. Kelurahan Tamanlanrea merupakan salah satu kelurahan dengan penyebaran COVID-19 yang sangat tinggi di Kota Makassar.

\section{METODE PELAKSANAAN}

Metode yang digunakan pada PKM kali ini terbagi menjadi tiga tahap, yaitu (1) Tahap persiapan, (2) Tahap pelaksanaan, dan (3) Tahap evaluasi. Tahap persiapan diawali dengan diadakannya persiapan untuk mensosialisasikan rencana pelaksanaan PKM kepada warga terutama ibu hamil di Wilayah Desa Tamanlanrea. Selain itu diadakan survei guna mencari kesepakatan waktu pelaksanaan PKM serta pendataan peserta penerima bantuan Covid. Pada 
tahap ini juga dilakukan persiapan penataan sembako yang dibutuhkan bagi Ibu hamil terutama dalampemenuhan gizi seimbang sebagai tambahan bahan pangan dalam masa pandemi yaitu beras, minyak goreng, gula, teh, susu, dan mie telor dan vitamin $\mathrm{C}$.

Tahap pelaksanaan PKM meliputi penetapan sasaran penerima bantuan dan pelaksanaan distribusi sembako dan vitamin C. Materi yang diberikan merupakan materi yang berdasarkan hal-hal yang berkaitan dengan Covid-19 dan pentingnya dalam pemenuhan gizi seimbang. Metode yang digunakan adalah metode kuantitatif dengan pendekatan cross sectional. Pengabdian kepada masyarakat ini untuk melihat gambaran peningkatan imunitas dengan konsumsi vitamin $\mathrm{C}$ dan gizi seimbang bagi ibu hamil untuk pencegahan Covid-19. Pemateri dalam kegiatan pengabdian kepada masyarakat ini adalah dua dosen yang memiliki keahliannya masing-masing, yang dimana yang pertama adalah Ibu Amriati Mutmainna,S.Kep.,Ns.,MSN selaku dosen yang ahli di bidang Keperawatan Medikal Bedah dan Ibu Sitti Nurbaya,S.Kep.,Ns.,M.Kes selaku dosen yang ahli di bidang Keperawatan Maternitas. Hal ini sangat sesuai dengan judul pengabdian kepada masyarakat ini dan sangat kompeten dibidangnya. Tahap Evaluasi pada tahap ini akan dilaksanakan evaluasi terhadap pemberian bantuanyang telah dilakukan. Setelah dilakukan evaluasi mendapatkan hasil bahwa sembako danVitamin $\mathrm{C}$ yang telah didistribusikan sudah diterima pada sasaran yang sesuai dengan rencanayaitu pada ibu hamil terdampak covid di Kelurahan Tamanlanrea

\section{HASIL DAN PEMBAHASAN}

Berdasarkan dari hasil kegiatan pelaksanaan pengabdian kepada masyarakat yang telah dilakukan oleh tim pengabdian masyarakat yang beranggotakan 7 orang, terdiri dari Ketua Tim, 1 Anggota Tim, dan 5 Mahasiswa yang terlibat didalamnya, maka disimpulkan bahwa hasil yang didapatkan yaitu :

\section{Distribusi Frekuensi Wanita Hamil berdasarkan Karakteristik Responden di Kelurahan Tamalanrea Kota Makassar}

Data yang didapatkan setelah dilakukannya pengabdian masyarakat di Kelurahan Tamalanrea Kota Makassar dapat dilihat pada table 1 sebagai berikut.

Tabel 1. Distribusi Frekuensi Wanita Hamil berdasarkan Karakteristik Responden di Kelurahan Tamalanrea Kota Makassar

\begin{tabular}{llcc}
\hline No. & Karakteristik Responden & Jumlah & Persentase \\
\hline 1 & Tingkat Pendidikan & 5 & \\
& SD & 10 & $10 \%$ \\
& SMP & 25 & $20 \%$ \\
& SMA & 5 & $50 \%$ \\
& D3 & 3 & $10 \%$ \\
& S1 & $6 \%$ \\
& S2 & 2 & $4 \%$ \\
& S3 & 0 & $0 \%$ \\
\hline 2 & Pekerjaan & & \\
& Pegawai Negeri Sipil (PNS) & 6 & $12 \%$ \\
& Pegawai Swasta & 12 & $24 \%$ \\
& Wiraswasta & 14 & $28 \%$ \\
& Ibu Rumah Tangga (IRT) & 18 & $36 \%$ \\
\hline 3 & Pendapatan Per Bulan & & \\
& < Rp 500.000,- & 15 & $30 \%$ \\
& Antara Rp 500.000,- sampai Rp 1.000.000,- & 14 & $28 \%$ \\
& Antara Rp 1.100.000,- sampai Rp 2.500.000,- & 19 & $38 \%$
\end{tabular}




\begin{tabular}{llcc}
\hline No. & Karakteristik Responden & Jumlah & Persentase \\
\hline Antara Rp 2.600.000,- sampai Rp 5.000.000,- & 2 & $4 \%$ \\
> Rp 5.000.000,- & 0 & $0 \%$ \\
\hline
\end{tabular}

Pada table 1. yang terpapar tersebut bisa disimpulkan mengenai distribusi frekuensinya bahwa tingkat pendidikan yang paling banyak pada wanita hamil di kelurahan Tamalanarea yaitu pendidikan SMA sebesar 25 orang dengan persentase $50 \%$ dari data yang didapatkan saat melakukan pengabdian kepada masyarakat. Adapun, data yang diperoleh yaitu data pekerjaan yang dimana jumlah terbesar yang didapatkan yaitu Ibu Rumah Tangga (IRT) yaitu sebanyak 18 orang dengan persentase sebesar $36 \%$ dari jumlah keseluruhan. Adapula data yang didapatkan mengenai pendapatan perbulan bervariasi, namun dari table diatas tersebut pula jumlah terbesar pendapatannya yaitu antara Rp1.100.000,- sampai Rp2.500.000,- yang diperoleh oleh responden yaitu sebanyak 19 orang dengan persentase sebesar $38 \%$.

Tingkat pendidikan pada wanita hamil yang berada di Kelurahan Tamalanrea tersebut kebanyakan sudah memiliki pendidikan yang memumpuni untuk diberikannya pengetahuan-pengetahuan yang menunjang kesehatan ibu hamil termasuk pengetahuan tentang COVID-19 dan juga mengenai gizi seimbang. Selain itu, pekerjaan pada wanita hamil yang berada di Kelurahan Tamalanrea rata-rata memiliki pekerjaan dan ada juga yang berprofesi sebagai Ibu Rumah Tangga (IRT) sehingga memungkinkan adanya peningkatan secara social ekonomi untuk meningkatkan imunitas ibu di masa pandemic COVID-19 sekarang ini. Selanjutnya, perolehan pendapatan yang diperoleh pun mencukupi untuk perbaikan gizi pula bagi para ibu hamil dikarenakan rerata pendapatannya yaitu antara Rp1.100.000,- sampai Rp2.500.000,- setiap perbulannya. Menurut Yaya, dkk (2017) menyatakan bahwa pengetahuan ibu rumah tangga dalam pencegahan COVID-19 sangat penting ditingkatkan. Ibu rumah tangga berperan penting dalam meningkatkan kesadaran dan berpartisipasi dalam pencegahan dan pengendalian penyakit.

\section{Evaluasi Peningkatan Pengetahuan Ibu Hamil terkait COVID-19 di Kelurahan Tamalanrea Kota Makassar}

Hasil pengabdian kepada masyarakat yang telah dilaksanakan pada bulan Oktober tahun 2021 ini bahwa adanya peningkatan pengetahuan para ibu hamil terkait COVID-19 di Kelurahan Tamalanrea Kota Makassar. Hal ini dibuktikan dengan antusiasme para ibu hamil yang berada di lingkup Kelurahan Tamalanrea ini dalam mengikuti pendidikan kesehatan yang diberikan oleh pemateri penyelenggara pengabdian kepada masyarakat ini. Dan juga didapatkan hasil bahwa terjadinya peningkatan pengetahuan berdasarkan pertanyaan secara langsung diberikan kepada ibu hamil mengenai pengetahuan terkait COVID-19, kebanyakan memberikan jawaban dengan benar secara spontan. Berdasarkan hasil literature review yang dilakukan oleh Yurissetiowati dan Baso (2021) bahwa melalui database ditemukan sebanyak 433 artikel. Jumlah artikel terpilih sesuai dengan kriteria inklusi terdapat 3 artikel. Kesimpulan dari literature review ini adalah Ibu hamil di beberapa wilayah Indonesia sebagian besar mempunyai tingkat pengetahuan yang baik tentang Covid-19, dan sebagian besar ibu hamil bersikap yang positif tentang Covid-19, serta ibu hamil tersebut sebagian besar tidak melakukan kunjungan rutin kehamilan di fasilitas pelayanan kesehatan. Dukungan dari petugas kesehatan, suami, dan keluarga untuk melakukan kunjungan kehamilan sangat diperlukan sebagai upaya deteksi dini komplikasi pada kehamilan sehingga diharapkan ibu dan bayi bisa sehat dan selamat.

Menurut Pramestiyani, dkk (2021) menyatakan bahwa pengetahuan ibu hamil bertambah $60 \%$ setelah dilakukan kegiatan upaya peningkatan pengetahuan ibu hamil 
tentang persiapan persalinan di masa pandemi covid-19 secara online melalui penyuluhan dengan dihadiri 16 orang ibu hamil.

Menurut Setyawan, dkk (2020) dalam Pelaksanaan pengabdian yang dijalankannya menyatakan bahwa bisa berjalan dengan lancar dikarenakan adanya dukungan aparat kelurahan Ngesrep, ibu-ibu hamil dan mempunyai bailita sangat kooperatif dan kemampuan civitas kampus yang terdiri dari dosen serta mahasiswa dalam berkomunikasi dan membuat metode yang interaktif.

Tren virus corona atau biasa disebut dengan Covid-19 merupakan pandemic yang belum berakhir pada saat ini. Sebagian besar Negara yang ada di dunia melaporkan bahwa lebih sedikit infeksi Covid-19 baru. Namun, hal ini merupakan data secara global yang menunjukkan pula bahwa pandemic belum berakhir. Adapun target dari semua Negara yaitu masuk kedalam bagian nol kasus baru selama empat minggu berturut-turut atau selama sebulan (WHO, 2021). Di Indonesia didapatkan data nasional mengenai summary update yang dikeluarkan oleh Satuan Tugas Penanganan Covid-19 bahwa pada 1 minggu terakhir terjadi penurunan kasus sebesar $-14,2 \%$. Pada pekan ini, terdapat 23 Provinsi yang mengalami kenaikan kasus, 11 Provinsi yang mengalami penurunan kasus. Adapun pada provinsi yang mengalami kenaikan, dengan kenaikan tertinggi terlihat di Jawah Tengah naik 21.3\%, disusul Riau naik 37,6\%, Sulawesi Selatan naik 80.3\%, Jawa Barat naik $4.8 \%$, dan Sumatera Barat naik 30.6\%. Adapun mengenai top 5 provinsi dengan jumlah kasus terendah, yaitu Maluku Utara sebanyak 4.357 jiwa, selanjutnya Gorontalo sebanyak 5.257 jiwa, kemudian Sulawesi Barat sebanyak 5.387 jiwa, lalu Bengkulu sebanyak 5.795 jiwa, dan terakhir yaitu Kalimantan Barat sebesar 6.410 jiwa (Satuan Tugas Penanganan Covid-19, 2021). Adapun data tersebut, yang perlu digarisbawahi adalah data yang terdapat pada Provinsi Sulawesi Selatan itu sendiri dikarenakan hal ini terkait dengan lokasi pengabdian masyarakat yang dilaksanakan. Keadaan yang dialami oleh Provinsi Sulawesi Selatan yaitu masih memiliki kenaikan persentase sebesar $80.3 \%$.

Menurut Iskandar, dkk (2021) menyatakan bahwa Penyuluhan kesehatan berupa pelayanan kesehatan pada ibu hamil di masa pandemi covi 19 dapat menurunkan resiko kematian pada ibu dan bayi. Pendidikan kesehatan dan demonstrasi tentang kesehatan pada ibu hamil dilakukan selama 4 minggu yang melibatkan keluarga ibu hamil. Setelah dilakukan kegiatan tersebut, dapat disimpulkan bahwa kegiatan pengabdian masyarakat berupa pelayanan kesehatan ada ibu hamil sangat membantu mereka dalam menghadapi kehamilan.

Adapun hasil penelitian yang dinyatakan oleh Budiarti, dkk (2021) bahwa sebagian besar ibu hamil memiliki pengetahuan, sikap, dan perilaku yang baik dalam pencegahan covid 19. Namun masih ditemukan perilaku ibu hamil yang tidak sesuai dengan protokol kesehatan, sehinga edukasi berkelanjutan bagi ibu hamil melalui leaflet, poster, media edukasi elektronik dan online, serta penyediaan sarana cuci tangan di fasilitas pelayanan kesehatan harus terus dilakukan. Selain itu diperlukan dukungan pemerintah untuk mengatur kebijakan dalam penerapan protokol kesehatan agar perilaku pencegahan Covid-19 tetap tinggi sehingga risiko kejadian Covid-19 dapat dikendalikan.

Berdasarkan data tersebut diatas pula-lah sehingga tim pengabmas semakin yakin untuk tetap menyelenggarakan pengabmas ini untuk meningkatkan pengetahuan masyarakat terkait COVID-19. Agar meningkat juga kesadaran masyarakat terhadap pengetatan protocol kesehatan keseharian ibu hamil. 


\section{Evaluasi Peningkatan Pengetahuan Ibu Hamil terkait Vitamin C dan Gizi Seimbang di Kelurahan Tamalanrea Kota Makassar}

Berdasarkan dari hasil pengabdian kepada masyarakat pula telah didapatkan data bahwa adanya peningkatan pengetahuan para ibu hamil terkait Vitamin $\mathrm{C}$ dan Gizi Seimbang di Kelurahan Tamalanrea Kota Makassar. Hal ini dibuktikan dengan kehadiran para ibu hamil yang berada di lingkup Kelurahan Tamalanrea ke lokasi pengabdian kepada masyarakat ini untuk mengikuti promosi kesehatan yang diberikan oleh pemateri penyelenggara pengabdian kepada masyarakat ini yang disertakan dengan pembagian vitamin $\mathrm{C}$ dan pemberian konsumsi agar gizi para ibu hamil yang berada di lingkup Kelurahan Tamalanrea seimbang. Dan juga didapatkan hasil pula bahwa terjadinya peningkatan pengetahuan berdasarkan pertanyaan-pertanyaan yang diberikan kepada ibuibu hamil yang menghadiri kegiatan pengabdian kepada masyarakat ini mengenai pengetahuan terkait Vitamin C serta Gizi Seimbang di masa pandemic COVID-19 ini, kebanyakan memberikan jawaban dengan benar. Sehingga, hal ini dapat disimpulkan bahwa terjadinya peningkatan pengetahuan setelah dilakukannya evaluasi secara observasional.

Menurut Suryana (2018) dalam bukunya, beliau menjelaskan bahwa vitamin C sangat dibutuhkan bagi semua orang untuk menjaga kesehatan tubuhnya. Kandungan vitamin $\mathrm{C}$ dalam buah duku berkhasiat untuk menjaga kekebalan tubuh serta berkhasiat juga untuk orang yang berada dalam masa pemulihan. Selanjutnya, menurut Milda Ini (2016) berasumsi mengenai gizi seimbang bahwa makanan merupakan faktor yang sangat penting bagi manusia. Sebagais alah satu kebutuhan pokok, manusia pasti berusaha untuk memenuhi kebutuhannya akan makanan, nbahkan sejak dalam kandungan. Saat masih janin, makanan yang dikonsumsi oleh ibu akan turut diserap oleh janin yang berada dalam kandungan. Setelah lahir dan tumbuh dewasa, manusia mulai bisa memilih dan berusaha untuk memenuhi kebutuhannya sendiri akan makanan.

Menurut Arjilio, dkk (2021) menyatakan bahwa literature review menunjukan: Penurunan jumlah sel T; Aktivitas Sel T CD8+ dan Th1 meningkat pada infeksi virus; Shifting Th1/Th2 terjadi selama kehamilan; Infeksi yang terjadi pada saat kehamilan sangat mungkin memberikan dampak yang buruk bagi ibu dan janin; dan Vaksinasi bisa meningkatkan pertahanan tubuh ibu dan janin terhadap penyakit infeksi. Imunitas seluler menjaga kestabilan fungsi tubuh ibu dan janin selama kehamilan lewat penyesuaian kuantitas antara sel Th1 dan Th2.

Menurut Praharsini (2021) menyatakan bahwa Ibu hamil termasuk salah satu kelompok rentan dalam kaitan dengan penularan Covid-19. Namun bagi ibu hamil, Covid-19 tidak saja memberikan dampak negative sebagaimana imej yang terbentuk selama ini. Tapi sesungguhnya pandemi Covid-19 juga memiliki dampak positif. Dampak negatif yang dirasakan oleh ibu hamil selama pandemi Covid-19 adalah timbulnya rasa ketakutan yang beragam, yang intinya ketakutan akan terinfeksi Covid-19 dan memengaruhi bayi yang dikandungnya. Namun, ibu hamil juga merasakan dampak positif selama pandemi Covid-19 karena hubungan keluarga lebih erat dan harmonis, lebih peduli terhadap kebersihan diri dan keluarga, lebih menjaga kesehatan, serta menjadi kreatif dalam memanfaatkan waktu luang.

Upaya yang dilakukan oleh ibu hamil selama pandemi Covid-19, terdiri atas upaya preventif dan upaya kuratif. Upaya preventif dilakukan dalam bentuk melakukan aktivitas fisik, seperti berolahraga, melakukan pekerjaanpekerjaan rumah tangga, mengonsumi makanan olahan sendiri, secara rutin dan teratur meminum air mineral dan susu kehamilan, memakan buah-buahan dan sayur-sayuran. Bagi ibu hamil yang bergejala atau positif terinfeksi Covid-19, upaya kuratif yang dilakukan terutama berkaitan dengan berolah raga dan secara rutin berjemur di pagi hari, serta mengonsumsi lebih banyak makanan yang bergizi, seperti buahbuahan dan sayuran dan banyak meminum air mineral 
sebagai pemenuhan asupan cairan tubuh. Selain itu, ibu hamil juga mengonsumsi vitamin (seperti Ester $\mathrm{C}$ dan vitamin-vitamin lain yang diresepkan oleh dokter) untuk menjaga imunitas dan untuk mempercepat penyembuhan (Praharsini, 2021).

Meskipun upaya yang dilakukan oleh ibu hamil dalam kaitan dengan pencegahan dan pengobatan serupa tapi tak sama, dalam upaya preventif ibu hamil lebih banyak mengkombinasikan aktivitas fisik dan berbagai asupan yang terkait dengan upaya peningkatan daya tahan tubuh. Sedangkan dalam upaya kuratif ibu hamil membatasi durasi aktivitas fisik dan lebih rutin dalam melakukan upaya-upaya penyembuhannya. Perbedaan asupan nutrisi yang dikonsumsi pun terletak pada suplemen vitamin, jika dalam upaya preventif konsumsi suplemen tidak begitu dihiraukan dan terfokus pada makanan yang dikonsumsi, maka dalam upaya kuratif, mereka cenderung menyeimbangkan antara asupan makanan dan suplemen untuk menjaga imunitas dan mempercepat kesembuhan (Praharsini, 2021).

Pandemi Covid-19 memberikan dampak yang beragam terhadap ibu hamil, dalam menjaga kesehatan diri dan janin diperlukan berbagai macam upaya begitupula dalam penanganan penyakit yang menjangkiti ibu hamil, terutama Covid-19. Tapi yang terpenting dalam melakukan keduanya tidak terlepas dari kesadaran dan konsisten ibu hamil dalam menjalankannya. Ibu hamil diharapkan menyibukkan diri dengan aktivitas yang sesuai dengan kondisinya agar tidak terpaku pada kecemasan yang timbul terkait dengan pandemi Covid-19 agar kesehatan mental ibu hamil tetap terjaga (Praharsini, 2021).

Menurut Anggraini dan Anjani (2021) menyatakan bahwa dalam literature review ini adalah seorang ibu hamil dalam masa pandemi ini membutuhkan nutrisi tambahan karna di masa pandemi ini ibu harus lebih menjaga imunitas tubuh maupun janin yang ada dalam kandungannya, bila biasanya seorang ibu hamil memerlukan 80.000 kalori selama kehamilan, maka kebutuhan pada masa pandemi harus lebih ditingkatkan dan diperhatikan lagi. Gizi lebih yang harus ditambahkan lagi pada ibu hamil masa pandemi adalah kebutuhan gizi harian, suplemen, zat besi, vitamin $\mathrm{C}$ dan kebutuhan makronutrien yang mengandung karbohidrat, protein dan lemak. Kehamilan juga dapat berdampak pada masalah makanan, untuk memenuhi kebutuhan nutrisi ibu hamil pada saat pandemi, ibu hamil dianjurkan untuk makan pagi setiap hari, makan makanan berserat tinggi dan perbanyak asupan cairan, terapkan pola makan sehat dan rajin berolahraga.

Berdasarkan hal-hal tersebut pula, tim pengabdian masyarakat memiliki antusias tinggi untuk meningkatkan kesehatan ibu hamil dengan meningkatkan system imunnya melalui pemberian Vitamin $\mathrm{C}$ ini dan juga peningkatan gizi dengan pemberian gizi seimbang.

\section{SIMPULAN}

Kesimpulan yang didapatkan setelah dilakukannya pengabdian kepada masyarakat di kelurahan Tamalanrea Kota Makassar bahwa sasaran responden pengabmas yang menjadi sasaran yaitu para Ibu Hamil. Data yang diperoleh kebanyakan memiliki pendidikan SMA sebesar 50\%, pekerjaan IRT sebesar 36\%, dan pendapatan perbulannya antara Rp 1.100.000,sampai Rp 2.500.000,- sebesar 38\%. Sehingga segala hal ini memiliki sangkut paut antar satu sama lain mengenai pengetahuan tentang COVID-19, Vitamin C, dan Gizi Seimbang. Serta keterkaitan antara penyediaan gizi seimbang bagi ibu hamil di masa pandemic COVID-19 ini yang masih melanda di sekitar kita.

Saran bagi ibu hamil yang sedang mengandung janin di masa pandemic COVID-19 ini sekiranya selalu memperhatikan protocol kesehatan dan jangan sampai lengah, serta selalu 
menjaga kondisi kesehatan ibu dan janin dengan selalu menjaga keseimbangan gizi. Saran bagi tenaga kesehatan agar selalu membantu ibu hamil untuk menjaga protocol kesehatan agar terhindar dari penyakit COVID-19 serta menjaga kehamilan dalam kondisi sehat dengan menerapkan gizi seimbang.

\section{Ucapan Terima Kasih}

Ucapan terimakasih kami haturkan kepada Yayasan Pendidikan Nani Hasanuddin Makassar yang telah memberikan support dan tidak lupa pula kami haturkan terimakasih pula kepada seluruh jajaran yang ada di STIKES Nani Hasanuddin Makassar. Adapun kami sampaikan ucapan terimakasih pula kepada seluruh pihak yang telah membantu dalam penyusunan ini hingga selesai.

\section{Daftar Pustaka}

Adriani, M \& Wirjatmadi, B. (2012). Pengantar Gizi Masyarakat. Jakarta: Kencana Prenada Media Group.

Agustina, Widya. (2015). Kandungan Vitamin C dan Uji Organoleptik Fruithgurt Kulit Buah Semangka dengan penambahan Gula Aren danKayu Secang. Naskah Publikasi.Universitas Muhammadiyah Surakarta.

Anggraini, N. N. dan Anjani, R. D. (2021). Kebutuhan Gizi Ibu Hamil pada Masa Pandemi Covid-19. Jurnal Pangan dan Gizi, Vol. 11, No. 01. p-ISSN : 2086-6429

Arisman, (2014). Gizi Dalam Daur Kehidupan. Jakarta: EGC.

Arjilio, T. Z., Runtukahu, Sylivia R. Marunduh., Hedison Polii. Peran Imunitas Seluler pada Ibu Hamil. Jurnal eBiomedik; 9(2) : 215-221. doi : https://doi.org/10.35790/ebm.9.2.2021.31796

Budiarti, A., Dewi, G. P. I., dan Azri, M. Z. (2021). Perilaku Pencegahan Covid-19 pada Ibu Hamil. Jurnal Ilmu Keperawatan Maternitas; Vol 4, No. 2.

Fatimah, St. (2011). Pola Konsumsi Ibu Hamil Dan Hubungannya Dengan Kejadian Anemia Defisiensi Besi, J. Sains \& Teknologi, Desember 2011. Vol. 7 No. 3 : 137-152. Paules CI, Marston HD, Fauci AS. Infeksi Coronavirus-Lebih dari Sekedar Pilek. JAMA.2020; 323 (8): 707-708. doi: 10.1001 / jama.2020.0757.

Iskandar, S., Indaryani, Assyura, I. A., Santi, O., dan Wulandari, E. (2021). Upaya Peningkatan Pelayanan Kesehatan pada Ibu Hami di Masa Pandemi Covid-19. Jurnal Pengabdian Masyarakat Bumi Rafflesia. p-ISSN : 2623-2111

Milda, I. (2016) Nutrisi Pintar Ibu Hamil dan Menyusui untuk Golongan Darah B. Penerbit Bhuana Ilmu Populer : Jakarta.

Pramestiyani, M., Larasati, E. W., dan Petralina, B. (2021). Upaya Peningkatan Pengetahuan Ibu Hamil tentang Persiapan Persalinan di Masa Pandemi Covid-19. Jurnal Abdikemas; Volume 3, Nomor $2 . \quad$ DOI : https://doi.org/10.36086/j.abdikemas.v3i2\%20Desember.940

Praharsini, A. A. (2021). Upaya Preventif dan Kuratif ala Ibu Hamil. Jurnal Emik, Volume 4, Nomor 2.

Satuan Tugas Penanganan Covid-19. (2021). Analisis Data Covid-19 Indonesia (Update Per 11 April 2021). Diakses pada tanggal 22 April 2021 yang diakses dari website https://covid19.go.id/berita/analisis-data-covid-19-indonesia-update-11-april-2021

Setyawan, A., Purnomo, F. A., Firdaus, J. A., dan Nugraheni, A. Sosialisasi Peningkatan Pengetahuan Ibu Hamil dan Balita dalam Pemantauan secara Mandiri pada Era Pandemik Covid-19 di Kelurahan Ngesrep Semarang. Seminar Nasional Pengabdian 
Kepada Masyarakat UNDIP 2020. Doi : https://proceedings.undip.ac.id/index.php/semnasppm2019/article/viewFile/395/250

Suryana, D. (2018). Manfaat Buah. Dayat Suryana Independent. Diakses pada tanggal 23 Juni 2021 yang diakses dari e-book dengan alamat website https://www.google.co.id/books/edition/Manfaat_Buah/MuR0DwAAQBAJ?hl=id\&g $\mathrm{bpv}=1 \& \mathrm{dq}=$ kandungan $+\mathrm{vitamin}+\mathrm{c}+$ adalah $\&$ printsec $=$ frontcover

WHO. (2021). Coronavirus Disease (Covid-19) pandemic. Diakses pada tanggal 22 April 2021 yang diakses dari website https://www.who.int/emergencies/diseases/novelcoronavirus-2019

Yaya S, Bishwajit G, Ekholuenetale M, Shah V, Kadio B, Udenigwe O. (2017) Knowledge of prevention, cause, symptom and practices of malaria among women in Burkina Faso. PLoS ONE. 12:e0180508

Yurissetiowati, Y. dan Baso, N. (2021). Tingkat Pengetahuan, Sikap, dan Kunjungan Kehamilan pada Ibu Hamil selama Pandemi Covid-19 : Literature Review. Jurnal Inovasi Penelitian, Vol. 2, No.6. doi: https://doi.org/10.47492/jip.v2i6.945 